\title{
Contents, Vol. 20, 1986
}

\section{No. 1 Basic Sciences}

Formic Acid in Human Single-Site Resting Plaque - Quantitative and Qualitative Aspects

Distler, W.; Kröncke, A 1

Studies of the Inhibitory Action of Intense Sweeteners on Oral Microorganisms Relating to Dental Health

Grenby, T.H.; Saldanha, M.G 7

Inorganic Phosphate Assay with the Ascorbic Acid or Stannous Chloride Method: Influence of Fluoride

Linden, A.H.I.M. v.d.; Meiring, H.D.; Bosch, J.J. ten; Arends, J 17

Experimental Evidence for a Gradient in the Solubility and in the Rate of Dissolution of Human Enamel

Theuns, H.M.; Driessens, F.C.M.; Dijk, J.W.E. van; Groeneveld, A 24

A Scanning Electron Microscope Study of Artificial Caries Lesion Formation

Ingram, G.S.; Fejerskov, O 32

Studies on the Formation of Laminations within Artificial Caries-Like Lesions of Enamei

Sato, K.; Yamamoto, $\mathrm{H} \quad 40$

In vivo Remineralization of Artificial Enamel Lesions by a Fluoride Dentifrice or Mouth-rinse

Corpron, R.E.; More, F.G.; Clark, J.W.; Korytnicki, D.; Kowalski, C.J 48

On the Properties of Fluoride Solutions Used for Topical Treatment and Mouth Rinse

Larsen, M.J.; Jensen, S.J 56

Influence of Fluoridating Varnishes on Dentine in vitro

Scholtanus, J.D.; Schuthof, J.; Arends, J 65

Animal Studies

Caries Activity in Hamsters Prenatally Exposed to Fluoride (Short Communication)

Fitzgerald, D.B.; Fitzgerald, R.J 71

Clinical Science

Radiographic and Observed Tissue Changes in Approximal Carious Lesions at the Time of Operative Treatment

Thylstrup. A.; Bille, J.; Qvist, V 75

Regression of Approximal Carious Lesions Diagnosed from Serial Standardized Bitewing Radiographs (Short Communication)

Pitts, N.B 85

IV Contents

Bilateral Dental Caries from the Individual Perspective: a Definition and a Statistical Test

for Its Existence (Short Communication)

Boffa, J.; Shwartz, ML; Ash, A.; Pliskin, J.S.; Gröndahl, H.G

Announcements $\quad 96$

No. 2 Basic Sciences

Early Natural Subsurface Caries. A SEM Study of the Enamel Surface before and after 
Remineralization

Möller, H.; Schroder, U 97

Solubility Behaviour of Whole Human Enamel

Driessens, F.C.M.; Theuns, H.M.; Borggreven, J.M.P.M.; van Dijk, J.W.E 103

Fluoride Distribution in the Mouth after Fluoride Rinsing

Weatherell, J.A.; Strong, M.; Robinson, C; Ralph, J.P 111

Hydrolytic Properties of SП3P $44 \mathrm{~F} 3$ (Short Communication)

Etcheverry, S.B.; Narda, G.E.; Apella, M.C.; Baran, E.J 120

Animal Studies

Cariostatic Evaluation of Cheeses with Diverse Physical and Compositional Character istics

Harper, D.S.; Osborn, J.C.; Hefferren, J.J.; Clayton, R

Clinical Science

Caries Prevalence and Gingivitis in 5-, 7- and 10-Year-Old Schoolchildren in The Hague between 1969 and 1984

Train, G.J.; König, K.G.; Ruiken, H.M.H.M.; Vogels, A.L.M.; Elvers, J.W.H

Effect of Chewing on the Secretion of Salivary Components during Fasting

Johansson, I.; Ericson, T 141

Abstracts

Abstracts of Papers Presented at the 32nd ORCA Congress

July 3-6, 1985, Stenungssund, Sweden 148

No. 3 Basic Sciences

Comparison of the in vivo Effect of a 0 and 1,500 ppmF MFP Toothpaste on Fluoride

Uptake, Acid Resistance and Lesion Remineralization

ten Cate, J.M.; Rempt, H.E 193

In vivo Remineralization of Plaque-Induced Initial Enamel Lesions-A Microradiographic

Investigation

Dijkman, A.G.; Schuthof, J.; Arends, J 202

Evaluation of Toothpastes by Their Ability to Assist Rehardening of Enamel in vitro

Gerrard, W.A.; Winter, P.J 209

In vitro Demineralization of Human Enamel in Artificial U-Shaped Grooves

Smits, M.T.; Arends, J 217

Contents V

Effect of Human Lysozyme on 2-Deoxyglucose Uptake by Streptococcus mutatis and Other

Oral Microorganisms

Twetman, S.; Lindqvist, L.; Sund, M.-L 223

Inactivation of Glucosyltransferase by a Protease Derived from Streptomyces globtsporus

Nara, Y.; Morioka, T 230

Effect of Aerobic and Anaerobic Atmosphere on Acid Production from Sorbitol in Suspen

sions of Dental Plaque and Oral Streptococci

Kalfas, S.; Birkhed, D 237

Factors Affecting pH Rise of Suspended Salivary Sediment

Tavss, E.A.; Eigen, E 244

Animal Studies

Morphological and Histochemical Aspects of Carious Dentine in Osborne-Mendel Rats

Lormée, P.; Weill, R.; Septier, D 251 


\section{Clinical Science}

Effects of Cheese on Experimental Caries in Human Subjects

Suva, M.F. de A.; Jenkins, G.N.; Burgess, R.C.; Sandham, H.J 263

Action of Fluoride on Initiation of Early Enamel Caries in vivo. A Microradiographical Investigation

Øgaard, B.; Arends, J.; Schuthof, J.; Rølla, G., Ekstrand, J.; Oliveby, A 270

Effect of a Chalk-Based Toothpaste on $\mathrm{pH}$ Changes in Dental Plaque in vivo

Duke, S.A 278

Relationship between Enamel Fluoride Levels, Degree of Fluorosis and Caries Experience in Communities with a Nearly Optimal and a High Fluoride Level in the Drinking Water (Short Communication)

Grobler, S.R.; van Wyk, C.W.; Kotze, D 284

No. 4 Basic Sciences

Effect of Pulsed Low Energy Infrared Laser Irradiation on Artificial Caries-Like Lesion

Formation

Nelson, D.G.A.; Shariati, M.; Glena, R.; Shields, C.P.; Featherstone, J.D.B289

Developmental and Metabolic Aspects of a Monobacterial Plaque of Streptococcus mutans C 67-1 Grown on Human Enamel Slabs in an Artificial Mouth Model. I. Plaque Data

Noorda, W.D.; van Montfort, A.M.A.P.; Purdell-Lewis, D.J.; Weerkamp, A.H 300

Developmental and Metabolic Aspects of a Monobacterial Plaque of Streptococcus mutans C 67-1 Grown on Human Enamel Slabs in an Artificial Mouth Model. II. Enamel Data

Noorda, W.D.; Purdell-Lewis, D.J.; van Montfort, A.M.A.P.; Weerkamp, A.H 308

Effect of Under- and Supersaturation with Respect to Some Apatites in Demineralizing

Buffers on Artificial Carious Lesion Formation in Human Tooth Enamel

Theuns, H.M.; Driessens, F.C.M.; van Dijk, J.W.E 315

Unstable Behavior of Magnesium-Containing Hydroxyapatites

Okazaki. M.; Takahashi, J.; Kimura, H 324

Fluoride Uptake from an Anti-Calculus NaF Dentifrice in vitro (Short Communication)

White. D.J.; Faller, R.V 332

Inhibition of Enamel Demineralization by Albumin in vitro (Short Communication)

Arends, J.; Schuthhof. J.; Christoffersen, J 337

Potentiometric Study of Dentine Permeability (Short Communication)

Santini, A $\quad 341$

VI Contents

Cell-Free Glucosyltransferase in Saliva (Short Communication)

Scheie, A.A.; Rölla, G 344

Clinical Science

Enamel Fluoride, Dental Fluorosis and Dental Caries among Immigrants to and Permanent Residents of Five Danish Fluoride Areas

Larsen, M.J.; Kirkegaard, E.; Poulsen, S.; Fejerskov, $0 \quad 349$

A Scanning Acoustic Microscope Study of the Small Caries Lesion in Human Enamel

Peck, S.D.; Briggs, G.A.D 356

Further Development of a Computer-Aided Image Analysis Method of Quantifying Radiolucencies in Approximal Enamel

Pitts, N.B.; Renson, C.E 361

Enamel Changes in Two Low-Fluoride Areas of Kenya 
Manji, F.; Baelum, V.; Fejerskov, O.; Gemert, W 371

Effect Induced by a Chalk-Based Toothpaste on the $\mathrm{pH}$ Changes of Plaque Challenged by a

High Sugar Diet over an 8-Hour Period (Short Communication)

Duke, S.A 381

Erratum 384

No. 5 Basic Sciences

In situ Appliance for the Investigation of Enamel De- and Remineralisation. A Pilot

Study

Creanor, S.L.; Strang, R.; Telfer, S,; MacDonald, L; Smith, M.J.; Stephen, K.W. ... 385

Microbiology and Acid/Anion Profiles of Enamel Surface Plaque from an in situ Caries

Appliance

Creanor, S.L.; Macfarlane, T.W.; Mackenzie, D.; Weetman, D.A.; Strang, R.; Stephan,

K.W 392

Microradiography and Electron Microprobe Analysis of Some Natural White and Brown

Spot Enamel Lesions with and without Laminations

Driessens, F.C.M.; Theuns, H.M.; Heijligers, H.J.M.; Borggreven, J.M 398

A Proposed Mechanism for the Effects of Saccharin on Glucose Metabolism by Streptococcus mutans

Brown, A.T.; Best, G.M 406

Fluoridation of Partially Demineralized Human Enamel in vivo. A Comparison of SIMS

and Microdrill Fluoride Analysis (Short Communication)

Reintsema, H.; Lodding, A.; Arends, J 419

Development and Initial Testing of a Model for in vitro Formation of Pit and Fissure Caries

(Short Communication)

Katz, S.; Park, K.K.; Stookey, G.K.; Schemehorn, B.R 424

pH Determination of APF Gels by an Iridium Electrode (Short Communication)

Pinzauti, S.; Papeschi, G.; La Porta, E 429

Isolation, Purification and Some Properties of a Potential Cariostatic Factor in Cocoa that

Lowers Enamel Solubility (Short Communication)

's-Gravenmade, E.J.; Jenkins, G.N 433

Effect of Fluoride on Diffusion of Calcium in Mucine: A Possible Mechanism Affecting

Remineralization of Carious Enamel (Short Communication)

Alhaique, F.; Riccieri, F.M.; Santucci, E.; Riccioni, G 437

Contents VII

Animal Studies

Cariogenicity of Lactitol in Program-Fed Rats (Short Communication)

van der Hoeven, J.S 441

Clinical Science

Comparison of Xeroradiographs and Two Types of Film for Detecting Caries in Approximal

Surfaces of Primary Teeth

White, S.C.; McMullin, K 444

An Evaluation of Agreement between Clinical and Radiographical Diagnosis of Approximal

Carious Lesions

Ruiken, H.M.H.M.; Truin, G.J.; König, K.G.; Elvers, J.W.H 451

$0.25 \%$ and $0.4 \%$ Amine Fluoride Gel for Weekly Topical Application. An in vivo Study on

Human Dental Enamel 
Goorhuis, J.; Purdell-Lewis, D.J 458

Effects on Artificial Enamel Lesions in vivo by Exposure to NaF Lozenges

Clark, J.W.; More, F.G.; Corpron, R.E.; Korytnicki, D.; Kowalski, C.J 465

Fluoride, Altitude and Dental Fluorosis

Manji, F.; Bælum, V.; Fejerskov, 0473

No. 6 Basic Sciences

In vivo Colonization of Salivary Pellicle by Haemophilus, Actinomyces and Streptococcus Species

Liljemark, W.F.; Fenner, L.J.; Bloomquist, C.G 481

Nonnutritive Sweeteners as Inhibitors of Acid Formation by Oral Microorganisms

Ziesenitz, S.C.; Siebert, G 498

Effects of Chewing Sorbitol Gum and Paraffin on Human Interproximal Plaque pH

Jensen, M.E 503

Lesion Formation in Abraded Human Enamel. Influence of the Gradient in Solubility and the Degree of Saturation of Buffer Solutions on the Lesion Characteristics

Theuns, H.M.; Driessens, F.C.M.; van Dijk, J.W.E 510

Bioavailability of Fluoride from Some Health Food Products in Man

Trautner, K.; Einwag, J 518

Use of the Single-Section Technique in Caries Research (Short Communication)

ten Cate, J.M.; Exterkate, R.A.M 525

Influence of the Consumption Frequency of Filled Chocolate Products on the Demineralization of Human Enamel in vivo. A Microhardness and Microradiographic Investigation (Short Communication)

van Herpen, B.P.J.M.; Arends, J 529

Clinical Science

Dental Caries in Danish 7-, 11- and 13-Year-Old Children in 1963, 1972 and 1981

Bille, J.; Hesselgren, K.; Thylstrup, A 534

Forecasting Future Caries Prevalence from Data in a National Recording System

Heidmann, J.; Poulsen, S 543

Caries-Preventive Effect of Duraphat ${ }^{\circledR}$ Varnish Applications versus Fluoride Mouthrinses:

5-Year Data

Kirkegaard, E.; Petersen, G.; Poulsen, S.; Holm, S.A.; Heidmann, J548

VIII Contents

Animal Studies

The Effect of Low Levels of Sodium Fluoride in Drinking Water on the Incidence of Dental

Caries in Rats (Short Communication)

Spuller, R.L.; Beiraghi, S.; Rosen, S,; Beck, F.M 556

Erratum 558

Announcements

34th Annual ORCA Congress 1987

559

ORCA-Rolex Prize; ORCA Summer School

Acknowledgements

561

Author Index 563

Subject Index 566 